\title{
Elevated $\mathrm{CD8}^{+} \mathrm{IL}^{-17^{+}}{ }^{\mathrm{Tc}} \mathrm{T}$ Levels and Their Correlation with Disease Activity in Patients with Rheumatoid Arthritis
}

\author{
Romatoid Artit Hastalarında Artmış CD8 ${ }^{+}$IL-17 ${ }^{+}$Tc17 Düzeyleri ve \\ Hastalık Aktivitesi ile Olan İlişkisi
}

\author{
Ning LI, ${ }^{1}$ Jie HAN, ${ }^{1}$ Jie-Ru ZHOU,, Jia-Yi WANG, ${ }^{1}$ Jie ZHANG, ${ }^{1}$ Song-Guo ZHENG ${ }^{2}$ \\ ${ }^{1}$ Department of Rheumatology, Tong Ji University Affiliated Shanghai East Hospital, Shanghai, China \\ ${ }^{2}$ Division of Rheumatology and Immunology, Department of Medicine, \\ Keck School of Medicine of the University of Southern Los Angeles, USA
}

Objectives: In this study, we aimed to determine the role of CD8 ${ }^{+} \mathrm{IL}-17^{+}$double-positive T cells (Tc17) in the pathogenesis and activity of rheumatoid arthritis (RA).

Patients and methods: The frequency and distribution of the Tc17 cells were identified using double immunofluorescent staining in peripheral blood mononuclear cells (PBMCs), synovial fluid mononuclear cells (SFMCs), and synovial tissues in RA patients. Soluble interleukin (IL)-17 levels were measured using the enzyme-linked immunosorbent assay (ELISA). Real-time polymerase chain reaction (PCR) was used to determine the IL-17 messenger ribonucleic acid (mRNA) in $\mathrm{CD} 8^{+} \mathrm{T}$ cells. The correlation between the Tc17 cells and RA clinical parameters, including C-reactive protein (CRP), erythrocyte sedimentation rate (ESR), rheumatoid factor (RF), and Disease Activity Score 28 (DAS 28), a test used for the evaluation of the 28 commonly affected joints in RA, was analyzed.

Results: The frequency of Tc17 in the PBMCs of the RA patients was higher compared to the healthy controls. The frequency of Tc17 cells in the SFMCs of the RA patients was also higher than that found in the RA PBMCs and OA SFMCs. The IL-17 mRNA expression in the RA CD8 $8^{+} \mathrm{T}$ cells was significantly higher than in the healthy controls. The levels of soluble IL-17 in the sera and synovial fluid of the RA patients were significantly higher than those of the healthy control and OA groups. There was a significant positive correlation between the frequency of Tc17 cells in the SFMCs and DAS 28 scores in the RA patients.

Conclusion: Our study results strongly demonstrated that a new Tc17 subset existed in RA patients and its frequency was significantly correlated with the disease activity of RA patients. Thus, our study suggests that Tc17 cells along with other IL-17producing cells, may play an important role in the pathogenesis of RA.

Key words: CD8+IL-17+ $\mathrm{T}$ cells; double immunofluorescent staining; interleukin 17; rheumatoid arthritis.
Amaç: Bu çalışmada CD8+IL-17+ çift pozitif T hücrelerinin (Tc17) romatoid artritin (RA) patogenezinde ve aktivitesindeki rolü belirlendi.

Hastalar ve yöntemler: Tc17 hücrelerinin sıklığı ve dağılımı, RA hastalarında periferik kan mononükleerhücrelerde (PBMC), sinoviyal sıvı mononükleer hücrelerde (SFMC) ve sinoviyal dokularda çift immünfloresan boyama ile belirlendi. Çözünür interlökin (IL)-17 düzeyleri, enzim bağlı immünosorbent test (ELISA) ile ölçüldü. $\mathrm{CD}^{+} \mathrm{T}$ hücrelerindeki IL-17 mesanger ribonükleik asiti (mRNA) tespit etmek için gerçek zamanlı polimeraz zincir reaksiyonu (PZR) kullanıldı. Tc17 hücreleri ve $\mathrm{C}$-reaktif protein (CRP), eritrosit sedimentasyon hızı (ESR), romatoid faktör (RF) ve RA'da en çok etkilenen 28 eklemi değerlendiren Hastalık Aktivite Skoru 28 (DAS 28) dahil olmak üzere, RA'nın klinik parametreleri arasındaki ilişki analiz edildi.

Bulgular: Romatoid artrit hastalarında PBMC'lerdeki Tc17 sıklığı, sağlıklı kontrollere göre daha yüksekti. Romatoid artrit hastalarında SFMC'lerdeki Tc17 sıklığı da, RA PBMC ve OA SFMC'lerde bulunanlara oranla daha yüksek bulundu. Romatoid artrit $\mathrm{CD} 8^{+}$ T hücrelerinde IL-17 mRNA ekspresyonu, sağlıklı kontrollere göre anlamlı düzeyde daha yüksekti. Romatoid artrit hastalarının serum ve sinoviyal sıvılardaki çözünür IL-17 düzeyi, sağlıklı kontrollere ve OA grubuna göre anlamlı düzeyde daha yüksekti. Romatoid artrit hastalarında SFMC'lerdeki Tc17 hücre sıklığı ve DAS 28 skorları arasında anlamlı pozitif bir ilişki tespit edildi.

Sonuç: Çalışma bulgularımız, RA hastalarında yeni bir Tc17 alt kümesinin mevcut olduğunu ve hücre sıklığının bu hastalardaki hastalık aktivitesi ile anlamlı düzeyde ilişkili olduğunu gösterdi. $\mathrm{Bu}$ nedenle, bu çalışma Tc17 hücrelerinin ve IL-17 üreten diğer hücrelerin RA patogenezinde önemli bir rol oynayabileceğine işaret etmektedir.

Anahtar sözcükler: CD8+IL-17+ $T$ hücreleri; çift immünfloresan boyama; interlökin 17; romatoid artrit.

Received: August 13, 2012 Accepted: September 23, 2012

Correspondence: Jie Han, PhD. Department of Rheumatology, Tong Ji University Affiliated Shanghai East Hospital, 150 Ji Mo Road, 200120 Shanghai, China. Tel: 8602161569573 e-mail: jiehancn@126.com 
Rheumatoid arthritis (RA) is a chronic inflammatory disease characterized by abnormal proliferation of synovial cells and the formation of pannus. $\mathrm{T}$ cells have been considered the main effector cells involved in the pathogenesis of RA. CD4 ${ }^{+}$effector cells [also known as T helper (Th) cells] were initially subdivided into two groups: Th type 1 (Th1) cells [producers of interferon gamma (IFN- $\gamma$ ), interleukin (IL)-2, and tumor necrosis factor alpha (TNF- $\alpha$ )] and Th2 cells (producers of IL-4 and IL-10). Autoimmune diseases, particularly autoimmune arthritis, were believed to be mainly driven by Th1 cells, ${ }^{[1]}$ but there were always some inconsistencies with this notion. Recently, a new subset of $\mathrm{CD}^{+} \mathrm{T}$ helper cells, named Th17 because they produce IL-17A, IL-17F, and IL-22, was implicated since they may be more important in the initiation and promotion of autoimmune and inflammatory diseases. ${ }^{[2]}$ Indeed, Th17 cells are the primary cause of inflammatory responses in a variety of autoimmune diseases, including Crohn's disease, RA, and ankylosing spondylitis (AS). ${ }^{[3,4]}$ Hence, the traditional paradigm for understanding the pathogenesis of autoimmune diseases that stated that Th1 and Th2 cells orchestrate autoimmune responses was challenged.

Likewise, in the $\mathrm{CD}^{+} \mathrm{T}$ cell compartment, Tc1 and Tc2 subsets also exist, and these are characterized by the same hallmark cytokines as Th1 and Th2. Recently, a subpopulation of $\mathrm{CD}^{+}$ $\mathrm{T}$ cells, a cell subset producing IL-17 (Tc17), was also discovered..$^{[5-7]}$ In addition, Henriques et al. ${ }^{[8]}$ reported that a trend for increased proportion in Tc17 cells was found in systemic lupus erythematosus (SLE) patients when they were compared with healthy controls. Furthermore, Ortega et al. ${ }^{[9]}$ showed that IL-17-producing CD8 ${ }^{+} \mathrm{T}$ lymphocytes from psoriasis skin plaques are cytotoxic effector cells that secrete Th17-related cytokines. They also determined that CD8 ${ }^{+} \mathrm{IL}-17^{+} \mathrm{T}$ cells share some key features with Th17 cells while exhibiting remarkable differential abilities attributable to the $\mathrm{CD} 8^{+}$lineage of $\mathrm{T}$ lymphocytes. These discoveries provide new insights into the functional resources of IL-17-producing cells from the human epidermis which could prove to be of potential interest for understanding the pathogenesis of psoriasis. However, its (CD8 $8^{+} \mathrm{IL}-17^{+} \mathrm{T}$ cells') expression, distribution, and role in RA has never been examined systemically.

In the current study, we demonstrated that Tc17 cells do exist in RA patients and that their frequency is correlated with disease activity. Tc17 expression seems to be specific to RA as the Tc17 cells are predominately distributed in the synovial fluid in RA patients, suggesting that they also play a role in joint inflammation. Thus, targeting Tc17 as well as Th17 may be therapeutic in patients with RA.

\section{PATIENTS AND METHODS}

Thirty-four consecutive seropositive patients with active RA were recruited for this study, and all patients (28 females, 6 males; mean age $50.2 \pm 16.9$ years; disease duration $73.8 \pm 49.6$ months) fulfilled the 1987 American College of Rheumatology (ACR) criteria for RA. ${ }^{[10]}$ Those who were pregnant or who had viral hepatitis, diabetes mellitus (DM), active infections, or other autoimmune diseases were excluded. Twenty age- and gender-matched healthy donors and $10 \mathrm{OA}$ patients were also enrolled as controls in the study.

Complete clinical and laboratory evaluations were performed for each patient, and age, gender and disease duration were recorded along with the erythrocyte sedimentation rate (ESR), the C-reactive protein (CRP), and rheumatoid factor (RF) levels. The presence of radiographic bony erosions was also noted as well as any medications that were being taken. This study was conducted in accordance with the Declaration of Helsinki and approved by the ethics committee of Shanghai East Hospital, which is affiliated with Tong Ji University. Written informed consent was also obtained from all of the participants.

The data was collected using a predesigned form, and standardized joint counts, including both tender and swollen joints, were recorded. In addition, the three-variable DAS 28 (DAS 28-3) in which tender joint count (TJC), swollen joint count (SJC), and ESR were examined was computed using the formula: ${ }^{[1]}$

DAS $28=\left[0.56 \mathrm{x} \sqrt{\mathrm{T}_{28}}+0.28 \mathrm{x} \sqrt{\mathrm{SW}_{28}}+0.70 \mathrm{xLn}(\mathrm{ESR})\right] \mathrm{x} 1.08+0.16$

One $20 \mathrm{~mL}$ peripheral blood sample was collected from each participant on the day of inclusion at the clinical evaluation, sent to the laboratory, and labeled with a code number. Analysis was then performed without knowing the participant's disease status. In addition, synovial tissue (ST) was obtained from five active RA patients and five OA patients (4 females, 1 male, mean age $65 \pm 7.2$ years) who had undergone an arthroscopy, arthroplasty, or synovectomy between March 2007 and December 2009. A $10 \mathrm{~mL}$ sample of synovial fluid (SF) was also collected from the swollen knee joints of ten RA patients and ten OA patients, respectively. Following the collection of the samples, the soluble IL-17 in the sera and the SF of the RA 
patients and controls were measured by a standard sandwich cytokine enzyme-linked immunosorbent assay (ELISA) procedure according to the instructions of the Human IL-17A High Sensitivity ELISA kit (eBioscience, Inc., San Diego, CA, USA).

\section{Indirect immunofluorescence}

A part of each synovial tissue was embedded in the optimum cutting temperature compound (Sakura Finetek USA, Torrance, CA, USA), snap-frozen, and stored at $-80{ }^{\circ} \mathrm{C}$ until needed. Six micrometer-thick cryosections were then placed on silane-coated slides and dried at room temperature. Next, the sections were fixed in cold acetone for five minutes at $4{ }^{\circ} \mathrm{C}$ and rinsed in phosphate buffered saline (PBS). To eliminate nonspecific protein binding, the samples were incubated with $2 \%$ fetal calf serum (FCS) in PBS for two hours at room temperature. This was followed by incubation with a mouse anti-human CD8 monoclonal antibody (1:100) (BD Biosciences, San Jose, CA, USA) for two hours at room temperature. Then the sections were rinsed in PBS and incubated with phycoerythrin (PE)-conjugated rat anti-mouse IgG1 (1:100) (BD Biosciences, San Jose, CA, USA) for one hour at room temperature in the dark. After washing the tissues again with PBS, they were permeabilized with permeabilization buffer. Following additional blocking with $2 \%$ FCS and washing with PBS, the sections were incubated with fluorescence iso-thiocyanate (FITC)-conjugated anti-human IL-17 monoclonal antibody (1:100) (eBioscience, Inc, San Diego, CA, USA) overnight at $4{ }^{\circ} \mathrm{C}$ in the dark. After more washing with $\mathrm{PBS}$, the sections were mounting with glycerine. The distribution of CD8 and IL-17 was observed using a Leica SP5 confocal microscope (Leica Geosystems AG, Gallen, Switzerland), and the numbers of $\mathrm{CD} 8{ }^{+} \mathrm{IL}-17^{+}$double-positive cells were determined using Leica QWin Pro software (Leica Microsystems, Wetzlar, Germany).

\section{Stimulation of peripheral blood mononuclear cells and synovial fluid mononuclear cells}

Peripheral blood mononuclear cells (PBMCs) and synovial fluid mononuclear cells (SFMCs) were purified from the PB and SF using centrifugation and a FicollHypaque gradient (Fresenius Kabi, Oslo, Norway). They were then adjusted to a final concentration of 106/ml in RPMI Medium 1640 supplemented with $10 \%$ heat-inactivated FCS, $1 \%$ glutamine/penicillin/ streptomycin, and a 2\% 4-(2-hydroxyethyl)-1piperazineethanesulfonic acid (HEPES) buffering agent.

\section{Immunofluorescent staining}

After in vitro stimulation with phorbol12-myristate13-acetate (PMA)/ionomycin/ monensin, $500 \mu \mathrm{L}$ of each $\mathrm{PB}$ and SF sample was diluted 1:1 (vol/vol), in Gibco ${ }^{\circledR}$ RPMI Medium 1640 (Life Technologies Ltd., Paisley, UK), which was supplemented with $2 \mathrm{mM}$ L-glutamine. Approximately $50 \mathrm{ng} / \mathrm{mL}$ of PMA (Alexis Corporation, Lausen, Switzerland), $1 \mu \mathrm{g} / \mathrm{mL}$ of ionomycin (Alexis Corporation, Lausen, Switzerland), and $2.079 \mu \mathrm{g} / \mathrm{mL}$ monensin (eBioscience Inc.,San Diego, CA, USA) were then added, and the samples were incubated for five hours at $37{ }^{\circ} \mathrm{C}$ in a humidified incubator with $5 \%$ carbon dioxide $\left(\mathrm{CO}_{2}\right)$ concentration. Each cultured $\mathrm{PB}$ and SF sample was aliquoted and stained in three different tubes (100 $\mu \mathrm{L} /$ tube) following an intracytoplasmatic permeabilization and staining protocol in order to analyze the intracellular expression of IL-17 within the CD8 T-cell subset. All cell aliquots were stained with IL-17 FITC (clone eBio64DEC17; eBioscience Inc., San Diego, CA, USA) according to the manufacturer's instructions for fixation and permeabilization. Next, monoclonal antibody (mAb) was added to each tube after staining the cells for surface expression of $\mathrm{mAb}$ directed against the $\mathrm{T}$ lymphocyte subset-anti-CD8 PE-Cy5.5 (clone RPA-T8; BD Biosciences, San Jose, CA, USA). Appropriately conjugated IgG antibodies were used as isotype controls.

Single-cell suspensions were prepared and stained for 30 minutes at room temperature in the dark with optimal dilutions of each mAb. The $\mathrm{CD}^{+} \mathrm{T}$ lymphocytes were identified according to their positivity for CD8 and typical light scatter, and the cytokine IL-17 production was evaluated within the $\mathrm{CD}^{+}$T-cell subsets on an electronic $\mathrm{CD}^{+}$gating after first acquiring of 20,000 total events. The identification and quantification of Tc17 were done based on the CD8 ${ }^{+} \mathrm{IL}-17^{+}$phenotype. Finally, expression of the cell surface markers and production of the cytokines were assessed using the BD FACSCalibur flow cytometer (BD Biosciences, San Jose, CA, USA), and data was analyzed using the Infinicyt ${ }^{\mathrm{TM}}$ software program (Cytognos S.L., Salamanca, Spain).

The study of mRNA expression of IL-17 from the $\mathrm{CD}^{+}$T-cells was performed by quantitative real-time reverse transcription polymerase chain 
reaction (RT-PCR). The total RNAs from the sorted $\mathrm{CD}^{+} \mathrm{T}$ lymphocytes were isolated using the TRIzol Reagent $^{\circledR}$ (Life Technologies Corporation, Carlsbad, CA, USA), and RNA integrity and quantification were analyzed using RNA 6000 Nano Chips in an Agilent 2100 Bioanalyzer (Agilent Technologies Inc., Waldbronn, Germany). Single-strand complementary deoxyribonucleic acid (cDNA) for a PCR template was synthesized from $1 \mu \mathrm{g}$ of total RNA using an oligo (dT) primer 12-18 and Moloney murine leukemia virus (M-MuLV) reverse transcriptase.

The specific primers for IL-17 and glyceraldehyde3-phosphate dehydrogenase (GAPDH) were as follows:

\section{IL-17-F (5'-CAACCGATCCACCTCACCTT-3'),}

\section{IL-17-R (5'-GGCACTTTGCCTCCCAGAT-3'),}

\section{GAPDH-F (5'-GCACCGTCAAGGCTGAGAAC-3'),}

\section{GAPDH-R (5'-ATGGTGGTGAAGACGCCAGT-3').}

Relative quantification of gene expression by realtime PCR was done using the Roche LightCycler ${ }^{\circledR} 480$ Real-Time PCR system (F. Hoffman-LaRoche Ltd., Basel, Switzerland), and reactions were performed with the following thermal profile: two minutes at $95{ }^{\circ} \mathrm{C}$ plus 50 cycles of 15 seconds at $95{ }^{\circ} \mathrm{C}, 15$ seconds at $55^{\circ} \mathrm{C}$, and 15 seconds at $72{ }^{\circ} \mathrm{C}$.

The quantitative real-time PCR results were analyzed with the sequencing detection software (F. HoffmanRoche Ltd., Basel, Switzerland), and quantification was performed using the qBasePlus software package (Biogazelle NV, Zwijnaarde, Belgium) (Biogazelle NV, Belgium).

\section{Statistical analysis}

The results of this study were expressed as mean \pm standard deviation (SD) ( $\bar{x} \pm s$.$) . The statistical$ evaluation of the data was analyzed using the oneway analysis of variance (ANOVA), and correlations between the groups were assessed by Spearman's correlation coefficient. Additionally, a correlation of the elevated degree in the Tc17 of RA was calculated as the $95 \%$ confidence interval (CI) using the formula $\left(\mathrm{x}_{1}-\mathrm{x}_{2}\right) \pm \mathrm{t}_{(0.05, v)} \mathrm{XS}(\mathrm{x1-x2)}$ in which $\mathrm{X} 1$ equals the average number of Tc17 cells in the RA group and X2 equals the average number of Tc17 cells in the control group. If the scope of the $95 \%$ CI didn't overlap, then the elevated degree was considered to be statistically significant. All statistical analyses were performed using the SPSS version 15.0 for
Windows software program (SPSS Inc., Chicago, IL, USA), and the differences were considered to be statistically significant when the $\mathrm{p}$ value was less than 0.05 .

\section{RESULTS}

\section{Elisa}

Using ELISA, we evaluated the level of soluble IL-17A in the sera and SF of the RA patients and OA control subjects and observed a significant increased level of IL-17A in the sera and SF of the RA patients compared with the other group $(57.83 \pm 15.66$ in the RA sera vs. $17.62 \pm 8.57$ in the OA sera; $p=0.038$ ) $(82.19 \pm 12.54$ in RA SF vs. $39.29 \pm 10.46$ in OA SF; $\mathrm{p}=0.031$ ) (Table 1). In the patients with RA, the IL-17A level was higher in the SF than the sera $(82.19 \pm 12.54$ vs. $57.83 \pm 15.66 ; \mathrm{p}=0.042)$ (Table 1$)$.

\section{Indirect immunofluorescence}

Direct observation of the synovium via a confocal microscope clearly demonstrated the colocalization of IL-17 and CD8 in the RA patients (Figure 1), but this was not detected in the OA group.

\section{Flow cytometry}

Using flow cytometry, we also evaluated the cell surface expression of CD8 and intracellular expression of the IL-17 cytokine of $\mathrm{CD}^{+} \mathrm{T}$ cells by the PBMCs or SFMCs from the RA patients and the $\mathrm{OA}$ control group following stimulation with PMA, ionomycin, and monensin. We observed a higher proportion of IL-17-producing $\mathrm{CD}^{+} \mathrm{T}$ cells within the PBMCs and SFMCs of the RA patients compared with the other group (PBMCs: $0.60 \pm 0.29 \%$ vs. $0.29 \pm 0.24 \%$, respectively; $\mathrm{p}=0.006$ ) and (SFMCs: $1.03 \pm 0.42 \%$ vs. $0.41 \pm 0.29 \%$, respectively; $\mathrm{p}=0.008$ ) (Table 2 and Figure 2). In addition, the frequency of Tc17 cells in the patients with RA was significantly higher in the SF than in the PBMCs (Table 2), which suggests that Tc17 cells not only exist in the peripheral

Table 1. Interleukin-17 levels in the sera and synovial fluid from the rheumatoid arthritis patients and control subjects

\begin{tabular}{lcc}
\hline Groups & Cases & IL-17 levels $(\mathrm{pg} / \mathrm{ml})$ \\
\hline Healthy control sera & 20 & $17.62 \pm 8.57$ \\
Rheumatoid arthritis sera & 34 & $57.83 \pm 15.66^{*}$ \\
Osteoarthritis SF & 10 & $39.29 \pm 10.46$ \\
Rheumatoid arthritis SF & 10 & $82.19 \pm 12.54^{\star} \#$ \\
\hline \multicolumn{2}{l}{ * Compared with HC and OA control groups (HC sera and OA SF), $<<0.05$; \# } \\
Compared with RA sera, p $<0.05$; SF: Synovial fluid.
\end{tabular}


(a) Healthy control-PBMCs

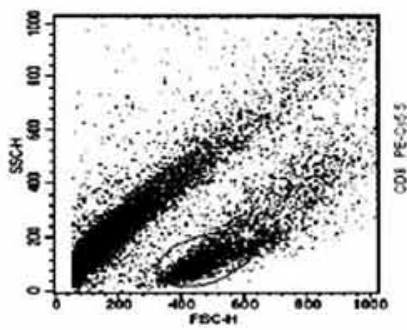

(c) OA-SFMCs

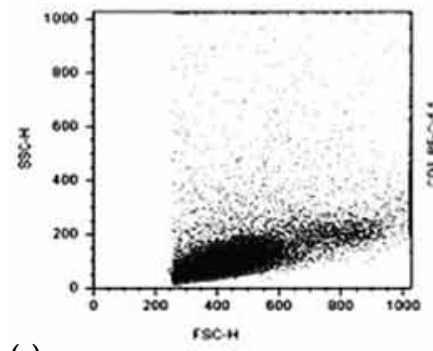

(e)

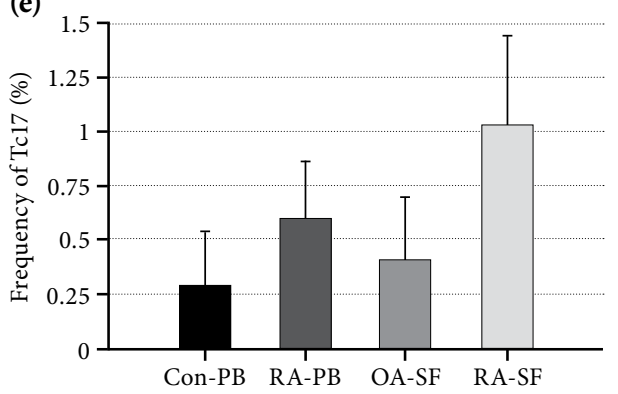

(b) RA-PBMCs
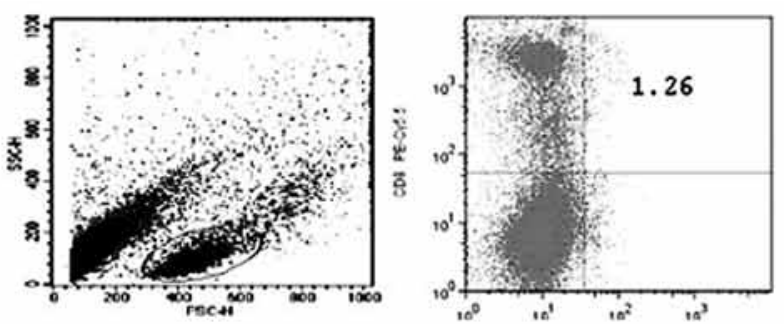

(d) RA-SFMCs
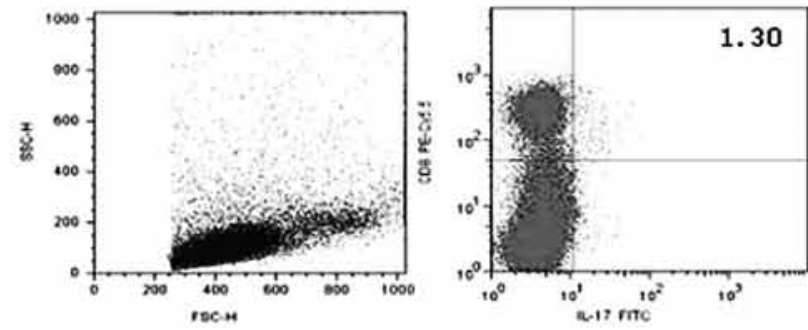

Figure 1. (a-d) The frequency of Tc17 cells in the peripheral blood mononuclear cells (PBMCs) and synovial fluid mononuclear cells (SFMCs) of the rheumatoid arthritis patients and the controls was examined by flow cytometry. After in vitro stimulation with phorbol myristate acetage, ionomycin, and monensin, the samples were incubated for five hours. Each cultured PBMC and SFMC sample was stained in order to analyze the intracellular expression of IL-17 within the CD8 ${ }^{+}$ T-cell subset (a representative experiment out of 11 is shown). (e) The frequency of IL-17-positive CD8 ${ }^{+} \mathrm{T}$ cells $(\mathrm{Tc17})$ in the RA patients, OA control group, and healthy controls are shown. The bars show the means.

blood of RA patients, but also that they migrate into the joints and are involved in the pathogenesis of arthritis syndromes.

In order to further determine whether increased Tc17 frequency is related to the transcription modulation in RA patients, we isolated the $\mathrm{CD}^{+}$ $T$ cells from the PBMCs of RA patients and healthy control subjects by FACS sorting. The relative expression of IL-17 mRNA in the $\mathrm{CD}^{+} \mathrm{T}$ cells from the two groups was determined by quantitative RT-PCR that was normalized to the GAPDH gene. The IL-17 mRNA level in freshly isolated $\mathrm{CD}^{+}$cells

Table 2. Frequencies of Tc17 cells in PBMCs and SFMCs (\%)

\begin{tabular}{lcc}
\hline Groups & Cases & Tc17/PBMCs or Tc17/SFMCs \\
\hline RA-PBMCs & 34 & $0.60 \pm 0.29^{* *}$ \\
HC-PBMCs & 20 & $0.29 \pm 0.24$ \\
RA-SFMCs & 10 & $1.03 \pm 0.42^{\# \#+}$ \\
OA-SFMCs & 10 & $0.41 \pm 0.29$ \\
\hline
\end{tabular}

** Compared with healthy controls (HC) PBMCs, $\mathrm{p}<0.01$; \#\# Compared with OA-SFMCs, $\mathrm{p}<0.01$; + Compared with RA-PBMCs, $\mathrm{p}<0.05$. in the RA patients was slightly higher than that of the controls (data not shown). However, after being stimulated with PMA, ionomycin, and monensin for five hours in vitro, the IL-17 mRNA level was much higher in the RA patients than in the healthy controls $(1.89 \pm 0.64$ vs 1.00 , respectively; $\mathrm{p}=0.035)$ (Figure 3).

We also sought to determine whether an increase in Tc17 cells has any functional significance in RA patients. To address this, we analyzed the Tc17 cell frequency with several items that reflect RA activity. As shown in Table 3, there was no correlation between the frequency of Tc17 cells and CRP, ESR, or RF ( $p>0.05$ ). Additionally, we also failed to observe a significant correlation between IL-17 sera levels and CRP, ESR, or RF ( $\mathrm{p}>0.05$ ). Furthermore, although there was no significant correlation between Tc17 in the PBMCs and DAS $28(\mathrm{r}=0.448 ; \mathrm{p}=0.144)$, there was a statistically positive correlation between the frequency of Tc17 cells in the SFMCs and the DAS 28 $(\mathrm{r}=0.818 ; \mathrm{p}=0.004)$ (Figure 4). This indicated that the increase in Tc17 cells, primarily in the inflammatory 
(a)

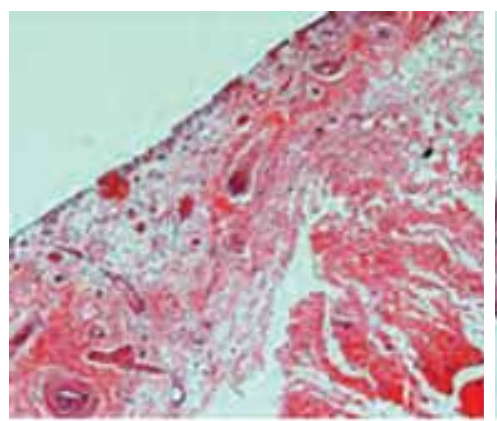

OA-synovium

(b)

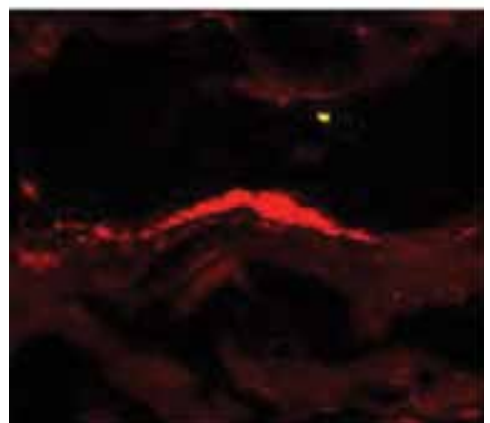

(c)

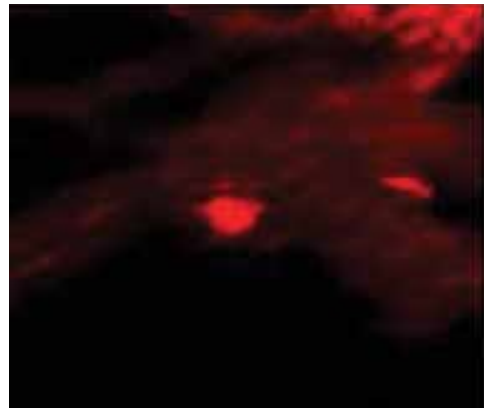

Anti-CD8

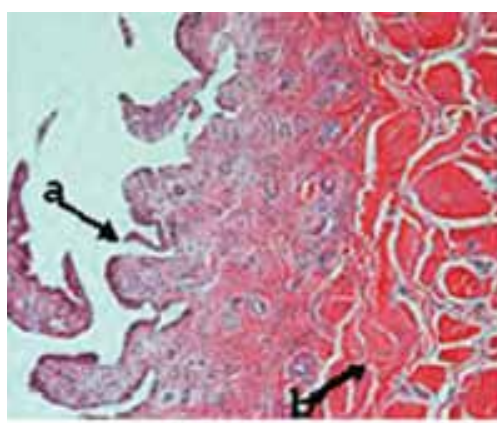

RA-synovium
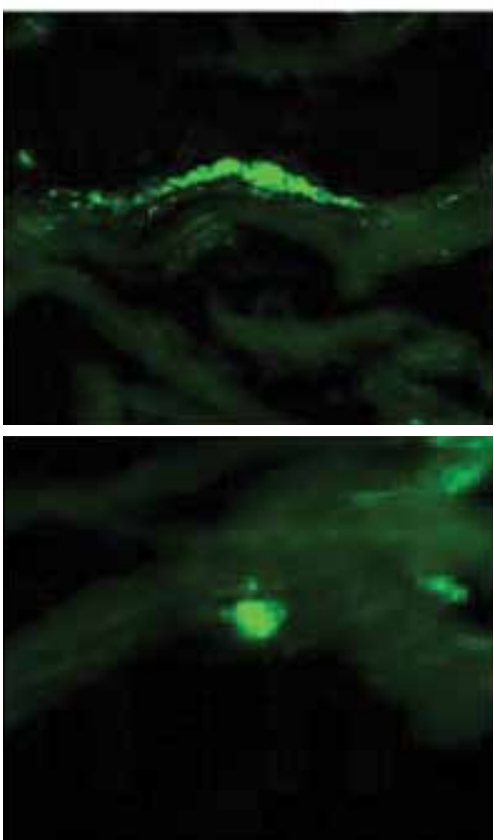

Anti-IL-17
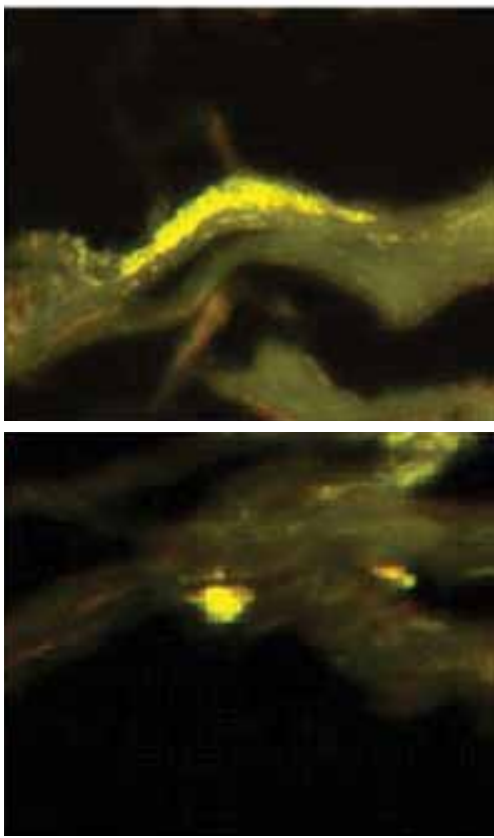

Merged

Figure 2. (a) (H-E x 200) staining of the rheumatoid arthritis (RA) and osteoarthritis synovium showing the infiltration of the inflammatory cells (arrow a) and hyperplasia of the fibrous tissue (arrow b) observed in the RA synovium. (b) Double-immunofluorescent staining of the synovium $(200 \mathrm{x})$ showing the CD8 ${ }^{+} / \mathrm{IL}-17^{+}$doublepositive cells infiltrating the synovium of the RA patient. This was assessed by a confocal microsope using anti-CD8/ anti-IgG1-phycoerythrin and anti-IL-17-FITC-conjugated monoclonal antibodies. (c) Double-immunofluorescent staining of the synovium (x400). A single CD8 ${ }^{+} / \mathrm{IL}-17^{+}$double-positive cell. One out of three experiments is shown.

joints, was associated with disease activity in the patients with RA.

\section{DISCUSSION}

Rheumatoid arthritis, the most typical and severe type of chronic inflammatory autoimmune disease, affects the joints and is accompanied by the destruction of cartilage and bone. The infiltration of the synovium by inflammatory lymphoid cells and phagocytes produces various proinflammatory cytokines, resulting in synovitis. ${ }^{[12,13]}$ Rheumatoid arthritis has been thought to be caused by $\mathrm{T}$ lymphocytes, especially the Th1 cell; however, in recent years, the idea that $\mathrm{RA}$ is predominantly driven by the Th1 subset of T-cells (the main producer of IFN- $\gamma$ ) has been questioned. In models of autoimmune diseases such as experimental autoimmune encephalomyelitis (EAE) and collageninduced arthritis (CIA), the inability to make or respond to IFN- $\gamma$ resulted in more severe disease rather than the abolishment of it. ${ }^{[14,15]}$ These findings led to the discovery of a new T-cell subset, the Th17 cells, by two separate study groups in 2005 , and this subset makes the signature cytokine IL-17. Since then, more and more evidence has shown that this subset is often the principal cause of 


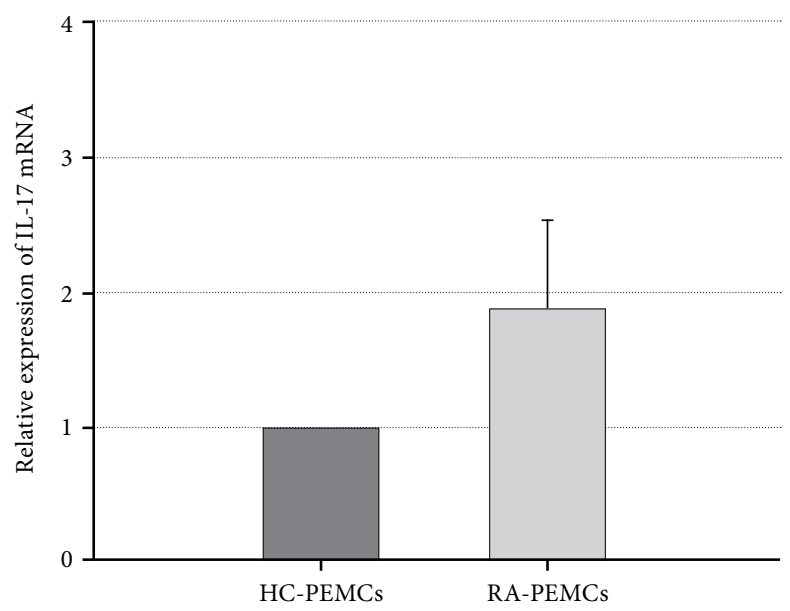

Figure 3. The IL-17 mRNA level of $\mathrm{CD}^{+} \mathrm{T}$ cells in the PBMCs from the healthy controls (HC) and rheumatoid arthritis (RA) patients. The IL-17 mRNA in the PBMCs of the healthy controls was designated as 1.00 , and the relative expression of IL-17 mRNA in PBMCs of the RA patients was $1.89 \pm 0.64$. The difference had statistical significance $(\mathrm{p}<0.05)$.

inflammation in many models of autoimmunity and human diseases.

Interleukin-17 has previously been demonstrated to exist in the synovial fluid of patients with early or established $\mathrm{RA}^{[16,17]}$ as well as in patients with $\mathrm{AS}^{[18,19]}$ and SLE. ${ }^{[20]}$ The Th17 subset has a functional reciprocal interrelationship with the classic Th1, Th2, and Treg cells, which are important players in the regulation of immune responses. ${ }^{[21,22]}$

In the $\mathrm{CD} 8^{+} \mathrm{T}$ cell compartment, a Tc17 subset that also produces IL-17 has recently been discovered ${ }^{[5]}$ which might also play a role in autoimmune diseases. ${ }^{[7]}$ Henriques et al. $^{[8]}$ first reported that an increased proportion of Tc17 was present in the PBMCs of SLE patients.

In this study, we examined the frequency and expression of Tc17 cells in the peripheral blood, SF,

Table 3. Correlation analysis between Tc17 and the disease activity parameters

\begin{tabular}{lcc}
\hline Parameters & \multicolumn{2}{c}{ Tc17/PBMCs } \\
\cline { 2 - 3 } & $\mathrm{r}$ & $p$ \\
\hline C-reactive protein & 0.22 & 0.25 \\
Erythrocyte sedimentation rate & 0.16 & 0.41 \\
Rheumatoid factor & 0.06 & 0.87 \\
Disease Activity Score 28 & 0.37 & $0.04^{*}$ \\
\hline PBMCs: Peripheral blood mononuclear cells; ${ }^{*} \mathrm{p}<0.05$. & & \\
\hline
\end{tabular}

and synovium of RA patients. Synovial fluid from healthy subjects is rarely available, so we compared the results of the SF from the RA patients with that of the OA control patients. The peripheral blood results were only compared with those of the healthy control subjects. We demonstrated that the level of soluble IL-17 was elevated in the sera and SF of the RA patients compared with the healthy subjects and OA control patients. In addition, the number of $\mathrm{CD} 8^{+}$ $\mathrm{T}$ cells that produced IL-17 was also significantly increased in the PBMCs and SFMCs of the RA patients compared with the other two groups. Hence, the expression of intracellular IL-17 and the increased levels of IL-17 mRNA were evident in the CD8 ${ }^{+}$ $\mathrm{T}$ cells which were sorted from their PBMCs and SFMCs after stimulation with PMA, ionomycin, and monensin. This suggests that besides $\mathrm{CD}^{+} \mathrm{T}$ cells, $\mathrm{CD}^{+} \mathrm{T}$ cells may be another principal source of IL-17 in the peripheral blood and SF of RA patients.

These observations are compatible with the idea that IL-17-producing cells contribute to the pathogenesis of inflammatory arthritis. As the DAS 28 score revealed, the frequency of Tc17 in the SFMCs of the RA patients correlated strongly with disease activity but not ESR, CRP, or RF. Other investigators ${ }^{[17]}$ have recently reported higher levels of IL-17-positive $\mathrm{CD}^{+}$T-cells in the peripheral blood of patients with

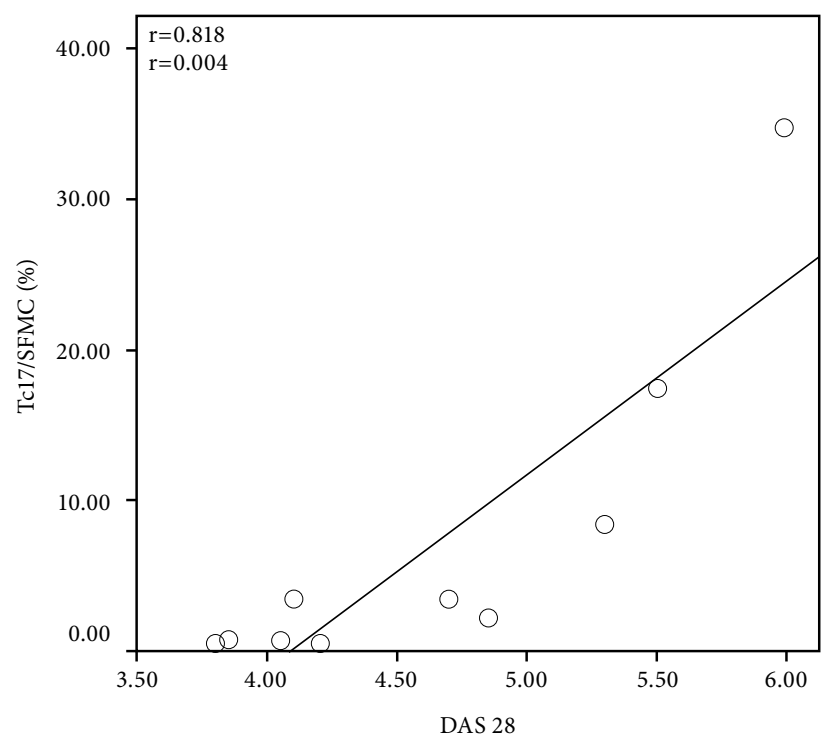

Figure 4. The frequency of Tc17 was positively correlated with the Disease Activity Score 28 (DAS 28). There was a statistically positive correlation between the frequency of Tc17 cells and the DAS 28 score $(r=0.37, \mathrm{p}<0.05)$, indicating that the $\mathrm{Tc} 17$ cell increase is correlated with disease activity in patients with RA. 
active RA. In those experiments, ${ }^{[17]}$ the cells were not examined by direct stimulation ex vivo, but they were investigated after being stimulated with phytohemagglutinin (PHA) for seven days. This was followed by restimulation with PMA and calcium ionophore. ${ }^{[17]}$

Although Th1 subsets are thought to be crucially involved in many autoimmune diseases, for example RA, recent studies have raised the possibility of different Th subsets being involved in the induction of autoimmunity. For instance, IL-17-producing T-cells serve as an effector T-cell subset involved in inducing inflammation and autoimmune tissue injury. ${ }^{[23]}$ In addition, elevated IL-17 levels have been detected in the synovial tissues from patients with RA, and IL-17 has been shown to be produced by synovial fibroblasts, gamma delta T-cells $(\gamma \delta \mathrm{T}$-cells), and natural killer (NK) cells. Now in this report, we have identified $\mathrm{CD} 8^{+} \mathrm{IL}-17^{+}$cells as another source of IL-17 according to our data. The levels of Tc17 cells and IL-17 in the SFMCs were both significantly higher than in the peripheral blood, suggesting that Tc17 may be one of the main cell sources that introduces the focal inflammation of RA.

Our study also showed that Tc17 exists in PB and SF. We especially found CD8/IL-17 double-positive cell expression in the synovium of the RA patients. In addition, we determined that the number of Tc17 cells was elevated in the RA patients compared with the control subjects (Table 2). This corroborates the findings of the other available studies. ${ }^{[8]}$ We also determined that the frequency of Tc17 in the SF was correlated with RA disease activity when assessed by the DAS 28 (Figure 4). The role of these cells remains unclear; however, their presence has been demonstrated in a mouse model in multiple sclerosis $(\mathrm{MS})^{[7]}$ and in psoriasis skin plaques in humans. ${ }^{[9]} \mathrm{Tc} 17$ cells display a greatly suppressed cytotoxic function and share some key features with the Th17 subset; ${ }^{[5,7,9]}$ therefore, we can speculate that the Tc17 cells cooperate with the Th17 subset with regard to similar functions in inflammatory conditions, including RA and other autoimmune diseases, ${ }^{[7,9]}$ infections, ${ }^{[7,24]}$ and anti-tumor immunity. ${ }^{[25]}$

Henriques et al. ${ }^{[8]}$ found a great functional heterogeneity of the Tc17 cells in SLE patients which shared features with both Th1 and Th17. Despite the apparent discrepancies between studies, the presence of Th17 and Tc17 cells suggests that they might contribute to acute and chronic inflammation in SLE; ${ }^{[26,27]}$ thus, future studies are needed to determine which of these cells plays a more important role in the pathogenesis of joint inflammation in RA.

\section{Conclusion}

In this study, we defined the frequency and expression of Tc17 cells in patients with RA versus both the healthy controls and the OA control group. In addition, a trend exists in RA patients for an increased proportion in Tc17 cells. Furthermore, the IL-17 mRNA levels of $\mathrm{CD}^{+} \mathrm{T}$ cells were also elevated in RA patients and correlated with RA disease activity. Moreover, there was expression of these cells in the synovial tissues of RA patients, which supports the hypothesis that IL-17-producing cells contribute to the pathogenesis of inflammatory arthritis. Taken as a whole, our findings suggest that a new T-cell subset, Tc17, along with other cells that produce IL-17 may play a contributory role in RA in the inflammatory process. They may also provide novel insights regarding the hypothetical role of Tc17 cells on disease pathogenesis. To further understand the role of T-cell subset dynamics in driving RA disease activity, more longitudinal studies are needed.

\section{Declaration of conflicting interests}

The authors declared no conflicts of interest with respect to the authorship and/or publication of this article.

\section{Funding}

This work was partially funded by a research grant from the Pudong New Area Science and Technology Commission of Shanghai, China (Grant No. PKJ2011-Y31).

\section{REFERENCES}

1. Dolhain RJ, van der Heiden AN, ter Haar NT, Breedveld FC, Miltenburg AM. Shift toward T lymphocytes with a $\mathrm{T}$ helper 1 cytokine-secretion profile in the joints of patients with rheumatoid arthritis. Arthritis Rheum 1996;39:1961-9.

2. McInnes IB, Schett G. The pathogenesis of rheumatoid arthritis. N Engl J Med 2011;365:2205-19. doi: 10.1056/ NEJMra1004965.

3. Brand S. Crohn's disease: Th1, Th17 or both? The change of a paradigm: new immunological and genetic insights implicate Th17 cells in the pathogenesis of Crohn's disease. Gut 2009;58:1152-67. doi: 10.1136/gut.2008.163667.

4. Shen H, Goodall JC, Hill Gaston JS. Frequency and phenotype of peripheral blood Th17 cells in ankylosing spondylitis and rheumatoid arthritis. Arthritis Rheum 2009;60:1647-56. doi: 10.1002/art.24568. 
5. Kondo T, Takata H, Matsuki F, Takiguchi M. Cutting edge: Phenotypic characterization and differentiation of human CD8+ $\mathrm{T}$ cells producing IL-17. J Immunol 2009;182:1794-8. doi: 10.4049/jimmunol.0801347.

6. Ciric B, El-behi M, Cabrera R, Zhang GX, Rostami A. IL-23 drives pathogenic IL-17-producing CD8+ T cells. J Immunol 2009;182:5296-305. doi: 10.4049/ jimmunol.0900036.

7. Huber M, Heink S, Grothe H, Guralnik A, Reinhard $\mathrm{K}$, Elflein K, et al. A Th17-like developmental process leads to CD8(+) Tc17 cells with reduced cytotoxic activity. Eur J Immunol 2009;39:1716-25. doi: 10.1002/ eji.200939412.

8. Henriques A, Inês L, Couto M, Pedreiro S, Santos C, Magalhães $M$, et al. Frequency and functional activity of Th17, Tc17 and other T-cell subsets in Systemic Lupus Erythematosus. Cell Immunol 2010;264:97-103. doi: 10.1016/j.cellimm.2010.05.004.

9. Ortega C, Fernández-A S, Carrillo JM, Romero P, Molina IJ, Moreno JC, et al. IL-17-producing CD8+ T lymphocytes from psoriasis skin plaques are cytotoxic effector cells that secrete Th17-related cytokines. J Leukoc Biol 2009;86:435-43. doi: 10.1189/JLB.0109046.

10. Arnett FC, Edworthy SM, Bloch DA, McShane DJ, Fries JF, Cooper NS, et al. The American Rheumatism Association 1987 revised criteria for the classification of rheumatoid arthritis. Arthritis Rheum 1988;31:315-24.

11. Prevoo $M L$, van 't Hof MA, Kuper $H H$, van Leeuwen MA, van de Putte LB, van Riel PL. Modified disease activity scores that include twenty-eight-joint counts. Development and validation in a prospective longitudinal study of patients with rheumatoid arthritis. Arthritis Rheum 1995;38:44-8.

12. Brennan FM, Foey AD, Feldmann M. The importance of $\mathrm{T}$ cell interactions with macrophages in rheumatoid cytokine production. Curr Top Microbiol Immunol 2006;305:177-94.

13. Firestein GS. Immunologic mechanisms in the pathogenesis of rheumatoid arthritis. J Clin Rheumatol 2005;11:S39-44.

14. Sabatino JJ Jr, Shires J, Altman JD, Ford ML, Evavold BD. Loss of IFN-gamma enables the expansion of autoreactive CD4+ $\mathrm{T}$ cells to induce experimental autoimmune encephalomyelitis by a nonencephalitogenic myelin variant antigen. J Immunol 2008;180:4451-7.

15. Chu CQ, Swart D, Alcorn D, Tocker J, Elkon KB. Interferon-gamma regulates susceptibility to collageninduced arthritis through suppression of interleukin-17. Arthritis Rheum 2007;56:1145-51.
16. Raza K, Falciani F, Curnow SJ, Ross EJ, Lee CY, Akbar AN, et al. Early rheumatoid arthritis is characterized by a distinct and transient synovial fluid cytokine profile of $\mathrm{T}$ cell and stromal cell origin. Arthritis Res Ther 2005;7:R784-95.

17. Daoussis D, Solomou EE, Karampetsou M, Bounia K, Tsanaktsi A, Giannopoulos G, et al. Th17 cells are increased in patients with active rheumatoid arthritis. Ann Rheum Dis 2008;67 Suppl II:ii152.

18. Kim HR, Lee SH, Kim HY. Elevated serum levels of soluble receptor activator of nuclear factors-kappaB ligand (sRANKL) and reduced bone mineral density in patients with ankylosing spondylitis (AS). Rheumatology (Oxford) 2006;45:1197-200.

19. Wendling D, Cedoz JP, Racadot E, Dumoulin G. Serum IL-17, BMP-7, and bone turnover markers in patients with ankylosing spondylitis. Joint Bone Spine 2007;74:304-5.

20. Garrett-Sinha LA, John S, Gaffen SL. IL-17 and the Th17 lineage in systemic lupus erythematosus. Curr Opin Rheumatol 2008;20:519-25. doi: 10.1097/ BOR.0b013e328304b6b5.

21. Zheng SG, Wang JH, Koss MN, Quismorio F Jr, Gray JD, Horwitz DA. CD4+ and CD8+ regulatory T cells generated ex vivo with IL-2 and TGF-beta suppress a stimulatory graft-versus-host disease with a lupus-like syndrome. J Immunol $2004 ; 172: 1531-9$.

22. Volpe E, Servant N, Zollinger R, Bogiatzi SI, Hupé P, Barillot $\mathrm{E}$, et al. A critical function for transforming growth factor-beta, interleukin 23 and proinflammatory cytokines in driving and modulating human $\mathrm{T}(\mathrm{H})-17$ responses. Nat Immunol 2008;9:650-7. doi: 10.1038/ni.1613.

23. Murphy CA, Langrish CL, Chen Y, Blumenschein W, McClanahan T, Kastelein RA, et al. Divergent pro- and antiinflammatory roles for IL-23 and IL-12 in joint autoimmune inflammation. J Exp Med 2003;198:1951-7.

24. Hamada H, Garcia-Hernandez Mde L, Reome JB, Misra SK, Strutt TM, McKinstry KK, et al. Tc17, a unique subset of CD8 T cells that can protect against lethal influenza challenge. J Immunol 2009;182:3469-81. doi: 10.4049/ jimmunol.0801814.

25. Hinrichs CS, Kaiser A, Paulos CM, Cassard L, SanchezPerez L, Heemskerk B, et al. Type 17 CD8+ T cells display enhanced antitumor immunity. Blood 2009;114:596-9. doi: 10.1182/blood-2009-02-203935.

26. Dardalhon V, Korn T, Kuchroo VK, Anderson AC. Role of Th1 and Th17 cells in organ-specific autoimmunity. J Autoimmun 2008;31:252-6. doi: 10.1016/j. jaut.2008.04.017.

27. Steinman L. A rush to judgment on Th17. J Exp Med 2008;205:1517-22. doi: 10.1084/jem.20072066. 